\title{
Engineering Tyrosine-Based Electron Flow Pathways in Proteins: The Case of Aplysia Myoglobin
}

\author{
Brandon J. Reeder,* Dimitri A. Svistunenko, Chris E. Cooper, and Michael T. Wilson \\ School of Biological Sciences, University of Essex, Wivenhoe Park, Colchester, Essex CO4 3SQ United Kingdom \\ Supporting Information
}

ABSTRACT: Tyrosine residues can act as redox cofactors that provide an electron transfer ("hole-hopping") route that enhances the rate of ferryl heme iron reduction by externally added reductants, for example, ascorbate. Aplysia fasciata myoglobin, having no naturally occurring tyrosines but 15 phenylalanines that can be selectively mutated to tyrosine residues, provides an ideal protein with which to study such through-protein electron transfer pathways and ways to manipulate them. Two surface exposed phenylalanines that are close to the heme have been mutated to tyrosines (F42Y, F98Y). In both of these, the rate of ferryl heme reduction
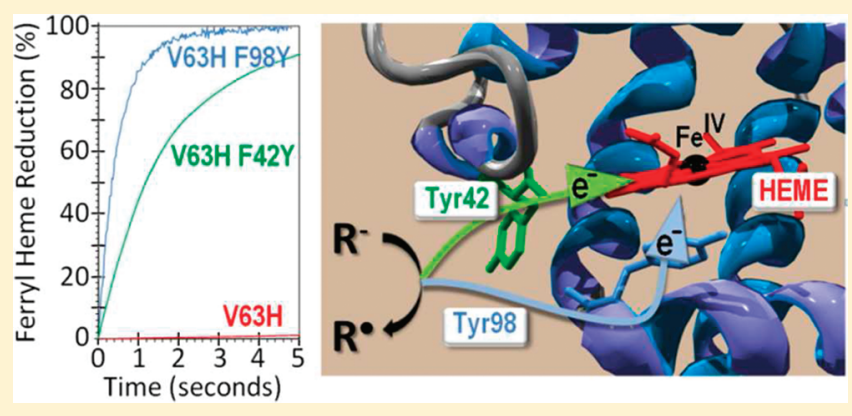
increased by up to 3 orders of magnitude. This result cannot be explained in terms of distance or redox potential change between donor and acceptor but indicates that tyrosines, by virtue of their ability to form radicals, act as redox cofactors in a new pathway. The mechanism is discussed in terms of the Marcus theory and the specific protonation/deprotonation states of the oxoferryl iron and tyrosine. Tyrosine radicals have been observed and quantified by EPR spectroscopy in both mutants, consistent with the proposed mechanism. The location of each radical is unambiguous and allows us to validate theoretical methods that assign radical location on the basis of EPR hyperfine structure. Mutation to tyrosine decreases the lipid peroxidase activity of this myoglobin in the presence of low concentrations of reductant, and the possibility of decreasing the intrinsic toxicity of hemoglobin by introduction of these pathways is discussed.

\section{INTRODUCTION}

In a recent article, Gray and Winkler have reviewed electron flow through metalloproteins pointing out the role played by certain aromatic amino acid residues (Tyr, Trp) that are capable of acting as redox intermediates. ${ }^{1}$ An important issue addressed by these authors is the mechanism through which such amino acids may facilitate long distance electron transfer though proteins between redox sites, making such transfers much more rapid than would otherwise be the case considering the distances between them. This mechanism depends on the residues being capable of forming radicals in the redox potential range normally available to biological reactions. By forming such "electron conduits", these amino acids act as way stations for hole-hopping, equivalent to electron transfer. The rate of electron flow through proteins has previously been demonstrated to be enhanced by addition of tryptophan residues to a mutated form of azurin from Pseudomonas aeruginosa, in which electron transfer between metal redox centers $19 \AA$ apart was increased by 2 orders of magnitude in a multistep electron transfer pathway over that of a single-step pathway. ${ }^{2}$ Other multistep electron transfer via an amino acid radical-hopping pathway, spanning two protein subunits, has been observed over distances of $35 \AA$ in ribonucleotide reductase. ${ }^{3,4}$ Such conduits can stem from a predominantly tyrosine-based transfer pathway but may also include tryptophan and cysteine residues, ${ }^{4,5}$ and a pure tryptophan conduit has also been observed in DNA photolyase. ${ }^{6}$ Previously, we have described results that show that tyrosine-based electron transfer pathways may be introduced into hemoglobin $(\mathrm{Hb})$ and myoglobin $(\mathrm{Mb})$, by mutating specific phenylalanine residues to tyrosine. This mutation adds a single atom (oxygen) to the protein, minimizing protein structural changes. It is, therefore, difficult to explain the dramatic increase in the rate of electron transfer that is caused by introduction of a tyrosine except by reference to the ability of this residue to access a radical state. In this system, however, the apparent rate constant for electron transfer, while increased, remains relatively low; we suggest that electron transfer is limited by the very low concentrations of the active species that are required to be present in defined states of protonation. ${ }^{7,8}$

To investigate further such tyrosine-based electron transfer pathways and to explore how these may be manipulated, we have used $\mathrm{Mb}$ from the sea slug Aplysia faciata (also known by its junior synonym, Aplysia lamacina). Aplysia $\mathrm{Mb}$ has no tyrosines but possesses 15 phenylalanine residues. This allows the redox inactive phenylalanine residues to be selectively changed to redox active tyrosines without extensive disturbance of the protein tertiary structure. The $\mathrm{V} 63 \mathrm{H}$ variant of the protein was used to provide a distal histidine (often present in

Received: December 16, 2011

Published: April 19, 2012 
other globins such as human $\mathrm{Mb}$ and $\mathrm{Hb}$ ), which assists in the coordination of small molecules at the sixth position of the heme and which acts as a proton donor/acceptor in the mechanism of $\mathrm{O}-\mathrm{O}$ bond scission in peroxides and hence the formation of the oxyferryl heme species. This system can be used as a test-bed for the investigation of electron movement through the protein and associated migration of a radical character in the opposite direction. By reacting the heme with hydrogen peroxide, one may generate a stable oxyferryl species, the kinetics of reduction to the ferric form of which one may study spectroscopically. Because the ferryl form may access the appropriate redox potential range, one can now explore the role tyrosine residues in the electron transfer from reductants in the medium to the buried heme group and the dependence of the kinetics of reduction on the precise position of such tyrosines. The tyrosine residues we have introduced (F42Y and F98Y) are close to the heme pocket, but are also surface exposed and thus positioned to allow them to act as redox cofactors between exogenously added reductants and the heme iron. The results show that the rate of the reduction of ferryl heme iron by electron donating agents, such as ascorbate and hydropyridinones, is increased in the presence of the tyrosine electron pathways. This effect is similar to that observed previously for human $\mathrm{Hb}$ and sperm whale $\mathrm{Mb}$; however, the increase of the rate of ferryl reduction, consequent on tyrosine introduction, was 2 orders of magnitude greater in Aplysia $\mathrm{Mb}$ than that observed in human $\mathrm{Hb}$ and sperm whale $\mathrm{Mb} .{ }^{9,10} \mathrm{We}$ also report that, although the oxidation of lipids by ferryl $\mathrm{Mb}$ is relatively unchanged by the mutations, the addition of these tyrosines significantly protects lipids against oxidative damage, in the presence of low concentrations of reductant. The location of the tyrosine in relation to the heme and protein surface is found to be critical in determining the kinetics of electron transfer between exogenous reductants and the heme iron.

One of the principal factors that has prevented acceptance of hemoglobin-based oxygen carriers (HBOCs) in mainstream medical care is a link to a significantly increased risk of myocardial infarction and mortality. ${ }^{11}$ One possible explanation for this toxicity is the inherent ability of $\mathrm{Hb}$ to participate in redox chemistry when outside its protected environment of the red blood cell or following hypoxia-reoxygenation. ${ }^{12-14}$ The ferryl oxidation state of $\mathrm{Hb}$ and various HBOCs have been shown to facilitate oxidation of lipid membranes. ${ }^{15}$ Our data strongly suggest that the introduction of tyrosine-based electron transfer pathways partially detoxifies $\mathrm{Mb}$ by inhibiting oxidation of lipid membranes in the presence of low concentrations of reductant. Thus, detoxifying the ferryl form, by enhancing the reduction of ferryl heme iron by reductants using these electron transfer pathways, could limit the oxidative damage that HBOCs cause.

\section{EXPERIMENTAL SECTION}

2.1. Materials. Catalase, ascorbate, lipoxygenase, sodium phosphate, and asolectin were purchased from Sigma-Aldrich (Poole, UK). Restriction enzymes were purchased from Fermentas (York, UK). Mutation of the $\mathrm{V} 63 \mathrm{H}$ protein to $\mathrm{V} 63 \mathrm{H} / \mathrm{F} 42 \mathrm{Y}$ and $\mathrm{V} 63 \mathrm{H} / \mathrm{F} 98 \mathrm{Y}$ was achieved by using the QuikChange II site directed mutagenesis kit by Stratagene (Agilent, Cheshire, UK), using primers from Fisher Scientific (Loughborough, UK). CP20 (deferiprone, 1,2-dimethyl-3hydroxypyrid-4-one) was given by Prof. Robert Hider, Department of Pharmacy, Kings College, London, UK.

2.2. Engineered Myoglobins. The gene for the $\mathrm{V} 63 \mathrm{H}$ variant of $\mathrm{Mb}$ from Aplysia faciata, contained in a pUC19 vector, was a kind gift from Prof. Francesca Cutruzzolà from the University of Rome, La Sapienza. To facilitate purification of the protein, a cleavable His-tag was added via mutation of the $5^{\prime}$ end of the protein sequence to add a FaqI restriction site and addition of an oligomer produced by Fischer Scientific. The $\mathrm{N}$ terminal sequence of the unmodified $\mathrm{Mb}$ is MetSerLeuSerAla-. Cleavage of the His-tag using thrombin (-LeuValProArgGlySer-) leaves the serine of GlySer- as the first serine of the normal sequence (GlySerLeuSerAla-). To enhance expression, the sequence was excised from the pUC19 vector (using unique NcoI and SalI restriction sites) and transferred into a pET28a vector with a T7 promoter. Vector was transformed into BL21 DE3 cells (Stratagene, UK) and added to Luria-Bertani medium, shaken at $120 \mathrm{rpm}, 37^{\circ} \mathrm{C}$. When optical density at $600 \mathrm{~nm}$ was 0.5 , isopropyl $\beta$ D-1-thiogalactopyranoside was added $(1 \mathrm{mM})$ with 5 -aminoleuvelinc acid $(500 \mu \mathrm{M})$ and ferric citrate $(100 \mu \mathrm{M})$ and incubated for a further 18-24 h. Cells were isolated by centrifugation $(15000 \mathrm{~g}$ ) and mechanically disrupted using an Avestin Emulsiflex C5. His-tagged Aplysia $\mathrm{Mb}$ (typically between 5 and $50 \mathrm{mg} / \mathrm{L}$ ) was purified using a nickel affinity column (GE Healthcare, UK) as per manufacturer instructions. Imidazole was removed through dialysis, and the tag was cleaved through incubation with bovine thrombin (Sigma-Aldrich, Poole, UK, 10U per mg protein). The thrombin cleavage of the his-tag was exceptionally slow, probably due to the close proximity of the cleavage site to the main $\alpha$-helical globular structure of the protein, as the protease recognition site included the first two amino acids of the protein tertiary structure. Therefore, the protein required incubation for 5 days with thrombin at room temperature to induce sufficient cleavage of the tag, incubated under sterile conditions to prevent protein degradation. Tag-free protein was purified using the nickel affinity column, and the thrombin was separated from the myoglobin by filtration through a Vivascience vivaspin filter ( $30 \mathrm{kDa}$ MWCO) and concentrated using a vivaspin or vivacell filter ( $5 \mathrm{kDa}$ MWCO).

Primers used were: 5'-3' CCCGACTCTGCCAACTACTTCGCTGACTTCAAAGGC and GCCTTTGAAGTCÄGCGAAGTAGTTGGCAGAGTCGGG for F42Y mutation and GCCAAGGAGCACGTAGGCTACGGTGTGGGATCTGCTCAA and TTGAGCAGATCCCACACCGTAGCCTACGTGCTCCTTGGC for F98Y mutation. PCR products were transformed into competent XL 1Blue cells (Stratagene) for amplification and sequenced by GATC-biotech, Germany.

2.3. Reduction Kinetics of Ferryl Aplysia Myoglobin. Ferryl $\mathrm{Mb}$ was formed by the reaction of ferric $\mathrm{Mb}(10 \mu \mathrm{M})$ with excess hydrogen peroxide $(30 \mu \mathrm{M})$. The kinetics of ferryl formation was monitored optically at 406 and $425 \mathrm{~nm}$, and the time for optimum ferryl formation was determined for each variant of $\mathrm{Mb}$. When ferryl formation was $>95 \%$, bovine catalase $(20 \mathrm{nM})$ was added to remove excess peroxide, and the reaction was allowed to proceed for further 1 min. Reductants ascorbate or CP20 (deferiprone) were mixed with the ferryl protein at a 1:1 ratio, diluting the protein to a final concentration of $5 \mu \mathrm{M}$. The kinetics of ferryl reduction to the ferric oxidation state was monitored optically using an Agilent 8453 diode array spectrophotometer or an Applied Photophysics SX20 stopped flow spectrophotometer fitted with a diode array detector. Rate constants were determined by fitting the time course $(406-425 \mathrm{~nm})$ to an exponential function using the Microsoft Excel Solver algorithm (least squared method) or using the Applied Photophysics ProK II program. Single and double rectangular hyperbola fits were obtained using the Microsoft Excel Solver algorithm. Confidence limits and $R$ squared values were calculated using Origin 8.0 by OriginLab.

2.4. Electron Paramagnetic Resonance Spectroscopy. EPR samples of the proteins reacting with $\mathrm{H}_{2} \mathrm{O}_{2}$ were made by the rapid freeze quenching (RFQ) method as previously described. ${ }^{16}$ All EPR spectra were measured on a Bruker EMX EPR spectrometer (X-band) at a modulation frequency of $100 \mathrm{kHz}$. A spherical high-quality Bruker resonator SP9703 and an Oxford Instruments liquid helium system were used to measure the low temperature EPR spectra. The EPR spectra of the blank samples (frozen water) were subtracted from the EPR spectra of the enzyme samples to eliminate the baseline caused by the resonator's walls, quartz insert, or quartz EPR tube. 
Table 1. Kinetic Parameters of Ferryl Heme Autoreduction and Reduction by Ascorbate and CP20 in Aplysia Myoglobin V63H, V63H/F42Y, and V63H/F98Y Mutants ${ }^{a}$

\begin{tabular}{|c|c|c|c|}
\hline \multirow[b]{2}{*}{ parameter } & \multicolumn{3}{|c|}{ protein } \\
\hline & $\mathrm{V} 63 \mathrm{H}$ & V63H/F42Y & V63H/F98Y \\
\hline \multicolumn{4}{|c|}{ Autoreduction } \\
\hline rate constant $k_{\mathrm{obs}}\left(\mathrm{s}^{-1}\right)$ & $1.44 \times 10^{-4} \pm\left(2.56 \times 10^{-6}\right)$ & $5.46 \times 10^{-3} \pm\left(4.04 \times 10^{-5}\right)$ & $9.95 \times 10^{-3} \pm\left(1.82 \times 10^{-5}\right)$ \\
\hline rate constant normalized to $\mathrm{V} 63 \mathrm{H}$ & 1 & 38 & 69 \\
\hline \multicolumn{4}{|c|}{ Ascorbate } \\
\hline rate constant $k_{\mathrm{obs}}, 50 \mu \mathrm{M}$ ascorbate $\left(\mathrm{s}^{-1}\right)$ & $1.65 \times 10^{-3} \pm\left(1.25 \times 10^{-5}\right)$ & $4.43 \times 10^{-1} \pm\left(2.48 \times 10^{-2}\right)$ & $1.95 \times 10^{0} \pm\left(1.46 \times 10^{-2}\right)$ \\
\hline Rrate constant normalized to $\mathrm{V} 63 \mathrm{H}$ & 1 & 269 & 1180 \\
\hline$K_{\mathrm{D}}$ for high affinity pathway $(\mu \mathrm{M})$ & & $1.8 \pm 0.13$ & $56.5 \pm 5.93$ \\
\hline$k_{\max }$ for high affinity pathway $\left(\mathrm{s}^{-1}\right)$ & 0 & $0.45 \pm 0.04^{*}$ & $4.3 \pm 0.30 * *$ \\
\hline \multicolumn{4}{|c|}{ CP20 } \\
\hline rate constant $k_{\mathrm{obs}}, 50 \mu \mathrm{M} \mathrm{CP} 20\left(\mathrm{~s}^{-1}\right)$ & $2.62 \times 10^{-4} \pm\left(1.58 \times 10^{-6}\right)$ & $3.05 \times 10^{-1} \pm\left(5.10 \times 10^{-3}\right)$ & $3.95 \times 10^{-1} \pm\left(7.75 \times 10^{-3}\right)$ \\
\hline rate constant normalized to $\mathrm{V} 63 \mathrm{H}$ & 1 & 1166 & 1510 \\
\hline$K_{\mathrm{D}}$ for high affinity pathway $(\mu \mathrm{M})$ & & $26.3 \pm 2.55$ & $514 \pm 20.9$ \\
\hline$k_{\max }$ for high affinity pathway $\left(\mathrm{s}^{-1}\right)$ & 0 & $0.45 \pm 0.03^{*}$ & $4.2 \pm 0.10^{* *}$ \\
\hline
\end{tabular}

${ }^{a}$ Note that the $k_{\max }$ for the $\mathrm{V} 63 \mathrm{H} / \mathrm{F} 42 \mathrm{Y}$ protein $(*)$ and the V63H/F98Y protein (**) are independent of reductant used. The errors in the values determination were found from a nonlinear regression analysis at a $95 \%$ confidence level.

The $g_{\|}=2$ component of the high spin (HS) ferric heme signal, obtained from the $\mathrm{Mb}$ control samples (i.e., not mixed with $\mathrm{H}_{2} \mathrm{O}_{2}$ ), has been subtracted from the EPR spectra of the protein radicals formed under peroxide treatment with individual for each spectrum coefficients of subtraction as described elsewhere. ${ }^{17}$ Thus, the free radical spectra presented in the Article are not contaminated with the HS ferric heme EPR signal. The freeze-quenched control samples were obtained by mixing a solution of $\mathrm{Mb}$ with a buffer in the freeze-quench apparatus. To measure intensities of the EPR signals, the procedure of spectra subtraction with a variable coefficient was used. ${ }^{18}$ Because different EPR samples are measured at slightly different microwave frequencies, depending on the slight variation in the physical characteristics of the EPR tubes, the same EPR signal in two different EPR samples can appear at slightly different values of the magnetic field. To increase the accuracy of the spectra subtraction, this error has been corrected by shifting each experimental spectrum to the left or to the right along the magnetic field in accordance with the difference between the frequency used to record an individual spectrum and some frequency value chosen as a standard for the whole array of experimental spectra. Absolute concentration of free radicals was determined by double integration of the EPR spectra measured at a low microwave power and relating the integrals to that of a concentration standard as described previously. ${ }^{17}$

Simulation of the EPR spectrum of the V63H/F42Y mutant treated with $\mathrm{H}_{2} \mathrm{O}_{2}$ was performed using SimPow, ${ }^{19}$ while the simulation parameters were found by the Tyrosyl Radical Spectra Simulation Algorithm (TRSSA), ${ }^{20}$ suggesting that the radical is on the introduced Y42.

2.5. Lipid Oxidation Measurements. Liposomes were formed by sonicating asolectin $50 \mathrm{mg} / \mathrm{mL}$ in $100 \mathrm{mM}$ sodium phosphate buffer containing $100 \mu \mathrm{M}$ DTPA for $10 \mathrm{~min}$. The asolectin was then forced under pressure using pressurized nitrogen gas ( 20 bar $)$ through a Northern Lipids extruder as previously described. ${ }^{21}$ Liposomes (200 $\mu \mathrm{g} / \mathrm{mL})$ were incubated with myoglobin $(1 \mu \mathrm{M})$ in $100 \mathrm{mM}$ sodium phosphate buffer containing $100 \mu \mathrm{M}$ DTPA. UV and visible spectra were monitored using an Agilent 8453 diode array spectrophotometer fitted with a multicell carriage. Kinetics of lipid conjugated diene formation was followed at $234 \mathrm{~nm}$, and the amount of conjugated diene formed was calculated from a three-point baseline drop from absorbance at 220 and $250 \mathrm{~nm}\left(\mathrm{Abs}_{234}-\left(0.533 \times \mathrm{Abs}_{220}+0.467 \times\right.\right.$ $\left.\mathrm{Abs}_{250}\right)$ ). The extinction coefficient for conjugated diene at $234 \mathrm{~nm}$ was $2.5 \times 10^{4} \mathrm{M}^{-1} \mathrm{~cm}^{-122}$ as calculated from a known concentration of 13-S-hydroperoxy 9-cis, 11-trans octadecadienoic acid prepared from the peroxidation of linoleic acid by soybean lipoxygenase, ${ }^{23}$ or $1.1 \times$ $10^{4} \mathrm{M}^{-1} \mathrm{~cm}^{-1}$ using the baseline drop method.

\section{RESULTS}

3.1. Tyrosine Redox Intermediates Facilitate Reduction of Ferryl Myoglobin. All three mutated forms of Aplysia $\mathrm{Mb}$ (V63H, V63H/F42Y, V63H/F98Y), when reacted with hydrogen peroxide, generate optical spectra indicative of ferryl $\mathrm{Mb}$. The kinetics of ferryl formation were not significantly different for the proteins, although all three were faster when compared to the wild type protein that lacked a distal histidine residue. ${ }^{17}$ The stability of the ferryl form was different in the three variants as can be seen from different rate constants for the ferryl autoreduction to the ferric derivative (Table 1). The presence of a tyrosine residue, either at position 42 or 98 , had an effect of a significant increase of the autoreduction rate (38or 69-fold, respectively). The autoreduction of the ferryl proteins did not follow first-order kinetics precisely, the time courses being more complex than a single exponential function, but were sufficiently close to use as a comparison with the pseudofirst-order kinetics observed for the reduction of ferryl $\mathrm{Mb}$ by ascorbate and CP20. The rate constant for autoreduction of $\mathrm{V} 63 \mathrm{H}$ ferryl ApMb $\left(1.44 \times 10^{-4} \mathrm{~s}^{-1}\right)$ is comparable to the previously reported autoreduction rate constants under similar experimental conditions for horse heart $\mathrm{Mb}\left(4.1 \times 10^{-4} \mathrm{~s}^{-1}\right)$ and human $\mathrm{Hb} \beta$ chain $\left(3.0 \times 10^{-4} \mathrm{~s}^{-1}\right)$, but lower than that for human $\mathrm{Hb} \alpha$ chain $\left(2.2 \times 10^{-3} \mathrm{~s}^{-1}\right){ }^{9,10}$

In these experiments, the radical produced concurrent with ferryl formation was allowed to decay before reductant was added. Therefore, all of our experiments on the reduction of ferryl heme and the effects of mutagenesis on this were conducted after compound II is formed (no compound I can be seen). A comparison of the time courses of the reduction of the ferryl Aplysia $\mathrm{Mb}$ variants by $50 \mu \mathrm{M}$ ascorbate is shown in Figure 1, and the rate constants are summarized in Table 1. The reduction of ferryl $\mathrm{V} 63 \mathrm{H} \mathrm{Mb}$ was slow, with a rate constant of $1.65 \times 10^{-3} \mathrm{~s}^{-1}$ at $50 \mu \mathrm{M}$ ascorbate, giving a half-life of $420 \mathrm{~s}$. Under identical conditions, the reduction of ferryl $\mathrm{V} 63 \mathrm{H} / \mathrm{F} 42 \mathrm{Y}$ protein was much faster, with a rate constant of reduction of $4.43 \times 10^{-1} \mathrm{~s}^{-1}$, decreasing the half-life of the ferryl species to $1.5 \mathrm{~s}$. This was a 269 -fold increase in reduction rate as compared to the tyrosine-free $\mathrm{V} 63 \mathrm{H}$ protein. The V63H/F98Y Aplysia Mb ferryl reduction was characterized by a rate constant of $1.95 \mathrm{~s}^{-1}$, further decreasing the half-life of the 

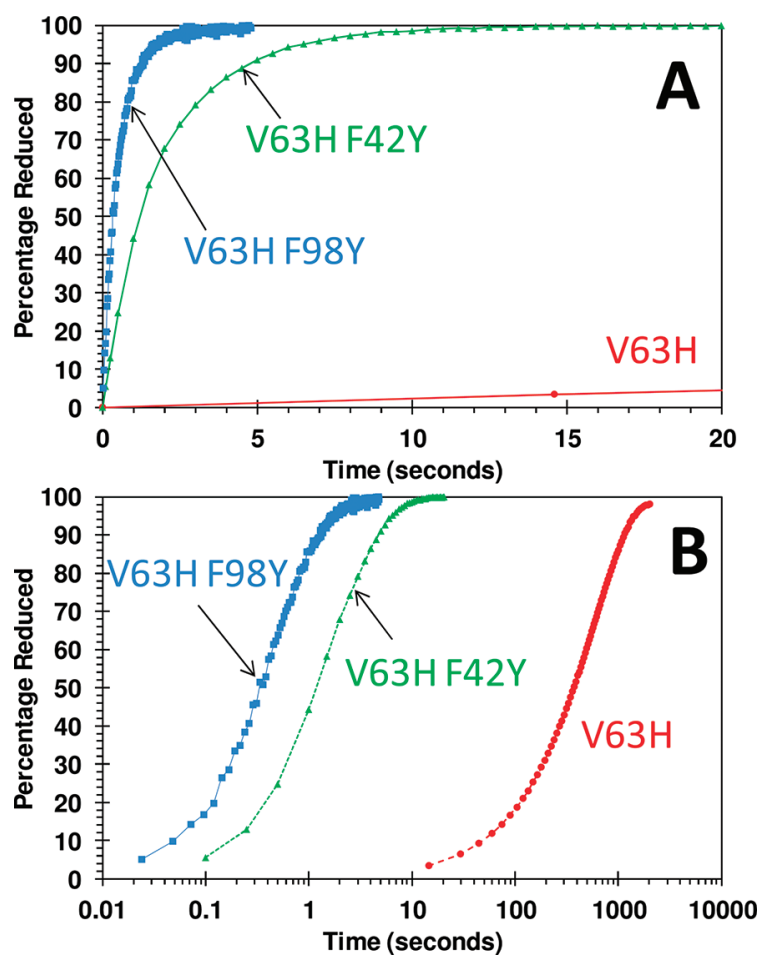

Figure 1. Kinetics of ferryl Aplysia myoglobin reduction by ascorbate. The three variants of Aplysia myoglobin, V63H (red ), V63H/F42Y (green $\boldsymbol{\Delta}$ ), and V63H/F98Y (blue $\mathbf{\square}$ ), all in the ferryl heme state and at $5 \mu \mathrm{M}$, were mixed with ascorbate $(50 \mu \mathrm{M})$, and the kinetics of reduction of the protein from ferryl to ferric was monitored optically. The time courses are presented in a linear time scale $(0-20 \mathrm{~s})(\mathrm{A})$ and logarithmic time scale $(0-10000 \mathrm{~s})$ (B). Symbols represent measured time points.

ferryl heme to $0.35 \mathrm{~s}$. Thus reduction of the V63H/F98Y Mb was 4.4-fold faster than the $\mathrm{V} 63 \mathrm{H} / \mathrm{F} 42 \mathrm{Y}$ protein and 1180 times faster than the $\mathrm{V} 63 \mathrm{H}$ protein. The reduction of ferryl $\mathrm{V} 63 \mathrm{H} / \mathrm{F} 98 \mathrm{Y} \mathrm{Mb}$ was so rapid that measurement of the rate constant could not be achieved accurately using standard spectrophotometer techniques and was consequently measured by a stopped flow spectroscopy.

Figure $2 \mathrm{~A}$ and $\mathrm{B}$ shows the ferryl $\mathrm{Mb}$ reduction rate constants (pseudofirst-order) as a function of ascorbate concentration. Data points were fitted to double rectangular hyperbola functions (plus an offset caused by autoreduction) representing two distinct pathways for the reduction of the ferryl heme by exogenous reductants: ${ }^{9,10}$

$$
k_{\mathrm{obs}}=\frac{k_{\max 1}[\mathrm{~S}]}{[\mathrm{S}]+K_{\mathrm{D} 1}}+\frac{k_{\max 2}[\mathrm{~S}]}{[\mathrm{S}]+K_{\mathrm{D} 2}}+A_{\mathrm{R}}
$$

where $S$ is the substrate (ascorbate) concentration, $k_{\max 1}$ and $k_{\max 2}$ are the maximum rate constants for electron transfer between the reductant and heme iron via the two different pathways, $K_{\mathrm{D} 1}$ and $K_{\mathrm{D} 2}$ are the corresponding dissociation constants of the two different sites in $\mathrm{Mb}$ for reductant, and $A_{\mathrm{R}}$ represents the ferryl autoreduction rate constant. We have previously shown that each hyperbola represents a distinct pathway for the reduction of the ferryl heme by exogenous reductants. ${ }^{9,10}$ One pathway is direct reduction of the ferryl heme iron by the reductant. It is present in all three Aplysia proteins examined and in the absence of the second pathway produces the rate constant profiles that can be fitted by a single rectangular hyperbola function. The second pathway is the
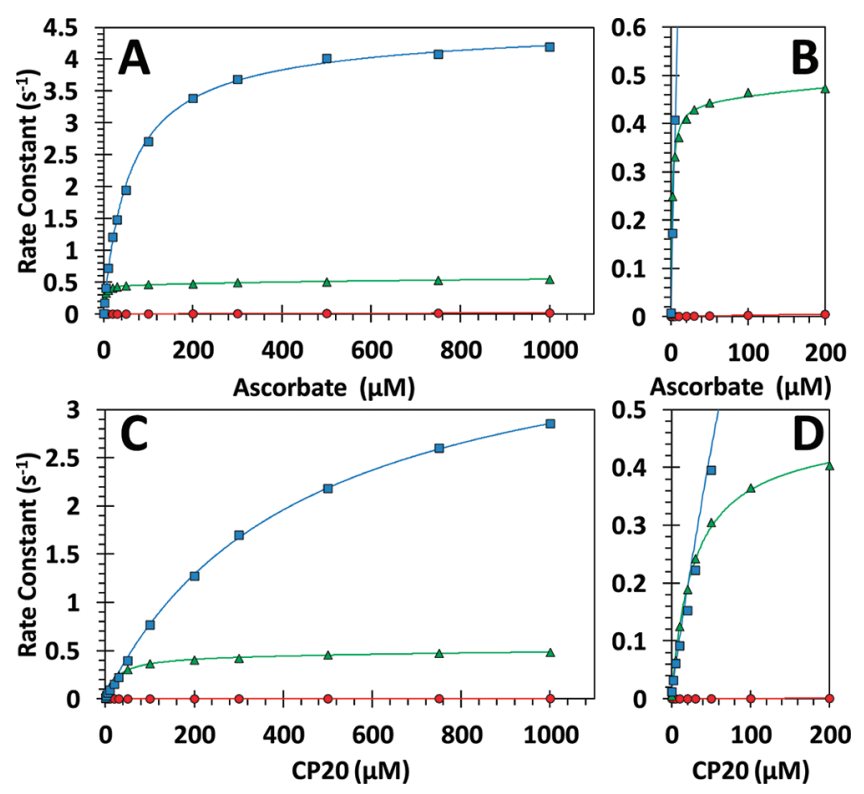

Figure 2. Pseudofirst-order rate constants of $5 \mu \mathrm{M}$ ferryl Aplysia myoglobins reduction to the ferric form by ascorbate (panels A and B) or CP20 (panels C and D): tyrosine-free $\mathrm{V} 63 \mathrm{H} \mathrm{Mb}$ variant (red $\bullet$ ), $\mathrm{V} 63 \mathrm{H} / \mathrm{F} 42 \mathrm{Y} \mathrm{Mb}$ (green $\boldsymbol{\Delta}$ ), and V63H/F98Y Mb (blue $\mathbf{\square})$. The rate constants were calculated from single exponential approximations of the time courses of the ferryl-to-ferric transformation that has been measured spectroscopically. Panels B and D represent a detailed view of the dependences shown in panels $\mathrm{A}$ and $\mathrm{C}$, respectively, but on a smaller range of the axes.

through-protein electron transfer pathway, present in the V63H/F42Y and V63H/F98Y proteins but not in V63H protein. When a rate constant profile is represented by a double rectangular hyperbola function, it typically indicates the presence of both the direct and the through-protein electron transfer pathways. ${ }^{9}$ The direct reductant-to-heme-iron electron transfer pathway $\left(K_{\mathrm{D} 2}\right)$ shows a very low affinity for the reductant with an apparent $K_{\mathrm{D}}$ value typically in the high millimolar range ${ }^{10}$ (not reported in this study due to uncertain accuracy of its determination). The low affinity pathway can be observed with the reduction of ferryl V63H/F42Y protein by a shallow increase in rate constant above $200 \mu \mathrm{M}$, where the contribution by the high affinity pathway ceases to significantly affect the rate of ferryl reduction in both ascorbate and CP20 (Figure 2). Nonlinear regression analysis of the V63H/F42Y ascorbate data yields an $R^{2}$ value of 0.9656 when fitted to a single hyperbola and 0.9987 when fitted to a double hyperbola, showing that a two-pathway mechanism is required to more accurately describe the data. This is not so apparent with the V63H/F98Y protein, showing only a minor improvement when fitting to a double hyperbola; however, the high $k_{\max }$ for the high affinity pathway suppresses that contribution of the low affinity pathway (at $1 \mathrm{mM}$, the lower affinity pathway represents $1.6 \%$ of the rate constant, as opposed to $22.5 \%$ for the $\mathrm{V} 63 \mathrm{H} / \mathrm{F} 42 \mathrm{Y}$ protein). Both the apparent $K_{\mathrm{D}}$ and the $k_{\max }$ of this low affinity pathway have been previously shown to be highly dependent on the nature of the reductant used, particularly on such properties as hydrophobicity, molecular size, and charge. 9,24 This is unlike the through-protein electron pathway that typically shows very high affinity (apparent $K_{\mathrm{D}}$ value ranging in the micromolar or high nanomolar range) and shows little effect of the chemical or physical properties of the electron-donating agent on the $k_{\max }{ }^{9,24}$ The $k_{\max }$ values for the 
through-protein electron transfer pathway for the V63H/F42Y and V63H/F98Y proteins are 0.45 and $4.3 \mathrm{~s}^{-1}$, respectively, with apparent $K_{\mathrm{D}}$ values in the low micromolar range (Table 1 ), the $K_{\mathrm{D}}$ for the $\mathrm{V} 63 \mathrm{H} / \mathrm{F} 98 \mathrm{Y}$ protein approximately 30 -fold higher than the $\mathrm{V} 63 \mathrm{H} / \mathrm{F} 42 \mathrm{Y}$ protein, showing that the affinity for the through-protein electron transfer pathway for the $\mathrm{V} 63 \mathrm{H} / \mathrm{F} 42 \mathrm{Y}$ is much higher, although at a lower $k_{\max }$ value (Figure 2A and B).

The hydroxypyridinone CP20 has previously been used as a ferryl reductant for horse $\mathrm{Mb}$ as the apparent $K_{\mathrm{D}}$ values for the two electron pathways are significantly different. ${ }^{24}$ The tyrosine-free $\mathrm{V} 63 \mathrm{H} \mathrm{Mb}$ exhibits very slow reduction, with enhanced reduction of ferryl $\mathrm{Mb}$ in the $\mathrm{V} 63 \mathrm{H} / \mathrm{F} 42 \mathrm{Y}$ and V63H/F98Y proteins (Figure 2C and D). The dependence on CP20 concentration of the rate constant for ferryl heme reduction in the tyrosine-free protein can be described by a single rectangular hyperbola. The kinetics for the two tyrosine containing proteins, however, fit to double rectangular hyperbola functions, similar to the case when ascorbate was used. The $k_{\max }$ of the high affinity pathway in the two tyrosinecontaining proteins is 0.45 and $4.2 \mathrm{~s}^{-1}$ for the $\mathrm{V} 63 \mathrm{H} / \mathrm{F} 42 \mathrm{Y}$ and $\mathrm{V} 63 \mathrm{H} / \mathrm{F} 98 \mathrm{Y}$ proteins, respectively, essentially identical to the $k_{\max }$ values with ascorbate (Table 1 ). The $K_{\mathrm{D}}$ values for CP20 reduction via the high affinity pathway are higher than those found using ascorbate as reductant, but there is still $\sim 20$-fold difference between the $\mathrm{V} 63 \mathrm{H} / \mathrm{F} 42 \mathrm{Y}$ and $\mathrm{V} 63 \mathrm{H} / \mathrm{F} 98 \mathrm{Y}$ proteins (Table 1). At $30 \mu \mathrm{M} \mathrm{CP20,} \mathrm{the} \mathrm{rate} \mathrm{constant} \mathrm{for} \mathrm{ferryl}$ reduction for the $\mathrm{V} 63 \mathrm{H} / \mathrm{F} 42 \mathrm{Y}$ protein is at a maximum difference of 1200 -fold higher as compared to the $\mathrm{V} 63 \mathrm{H}$ protein. At $100 \mu \mathrm{M} \mathrm{CP20,} \mathrm{the} \mathrm{rate} \mathrm{constant} \mathrm{for} \mathrm{ferryl} \mathrm{reduction}$ for the $\mathrm{V} 63 \mathrm{H} / \mathrm{F} 98 \mathrm{Y}$ protein is 1600 -fold higher as compared to the $\mathrm{V} 63 \mathrm{H}$.

3.2. Changes in Protein Radical Formation as a Result of the Through-Protein Electron Flow Pathway. Figure 3 shows the mutant Aplysia Mb EPR spectra before and after

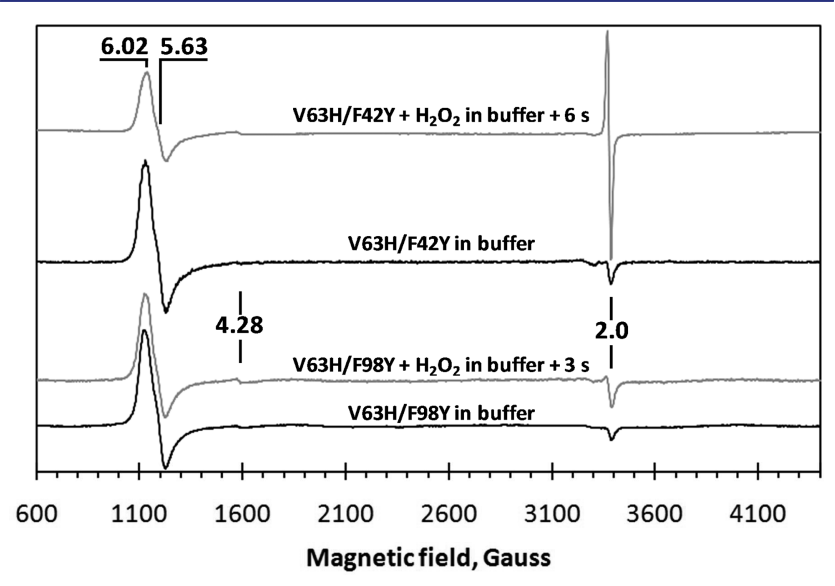

Figure 3. EPR spectra of the Aplysia myoglobin variants in $50 \mathrm{mM}$ sodium phosphate buffer ( $\mathrm{pH}$ 7.4) freeze-quenched after mixing with either the same buffer or the buffer containing $\mathrm{H}_{2} \mathrm{O}_{2}$. The V63H/F42Y $+\mathrm{H}_{2} \mathrm{O}_{2}$ and $\mathrm{V} 63 \mathrm{H} / \mathrm{F} 98 \mathrm{Y}+\mathrm{H}_{2} \mathrm{O}_{2}$ samples were quenched 6 and $3 \mathrm{~s}$, respectively, after myoglobin was mixed with the $\mathrm{H}_{2} \mathrm{O}_{2}$ solution; these time points correspond to maximal free radical concentrations (see Figure 4). The concentrations of the proteins and peroxide were always $80 \mu \mathrm{M}$ after mixing. The spectra were obtained at $10 \mathrm{~K}$ at the following instrumental conditions: microwave frequency $\nu_{\mathrm{MW}}=9.469$ GHz, microwave power $P=3.2 \mathrm{~mW}$, modulation amplitude $A_{\mathrm{m}}=5 \mathrm{G}$, time constant $\tau=82 \mathrm{~ms}$, scan rate $v=22.6 \mathrm{G} \mathrm{s}^{-1}$, number of scans per spectrum NS $=1$. reacting with equimolar hydrogen peroxide. The $\mathrm{Mb}$ samples with no hydrogen peroxide added show similar spectra, typical of high spin ferric heme myoglobin, with two $g$-values close to $g$ $=6$ and the third value at $g=2.00$. The intensities of these EPR signals decrease on peroxide addition as the ferric heme is oxidized to the EPR silent ferryl heme state. Accompanying this spectral change is a moderate increase in the $g=4.28 \mathrm{EPR}$ signal, which originates from the nonheme ferric iron in a rhombic coordination ${ }^{25}$ and is indicative of some peroxide induced heme degradation. Furthermore, addition of $\mathrm{H}_{2} \mathrm{O}_{2}$ to the $\mathrm{Mb}$ mutants results in formation of free radicals with the EPR signals at $g=2.00$. These signals are shown in more detail in Figure 4A. The V63H mutant shows no appreciable free radical formation $6 \mathrm{~s}$ after mixing with equimolar amount of $\mathrm{H}_{2} \mathrm{O}_{2}$. In contrast, introduction of a tyrosine in position 42 or 98 , in addition to the $\mathrm{V} 63 \mathrm{H}$ mutation, allows detection of the free radicals, although with very different yields in the V63H/ F42Y and V63H/F98Y mutants.

Figure 4B shows the kinetic dependences of the free radicals formed in the mutants following hydrogen peroxide addition. No free radical is observed in the $\mathrm{V} 63 \mathrm{H}$ protein. The time course for the radical in the $\mathrm{V} 63 \mathrm{H} / \mathrm{F} 42 \mathrm{Y}$ mutant shows the radical reaches relatively high concentrations approaching 10 $\mu \mathrm{M}$ at $6 \mathrm{~s}$, which constitutes $12.5 \%$ of total protein concentration. The maximal concentration of the radicals in the $\mathrm{V} 63 \mathrm{H} / \mathrm{F} 98 \mathrm{Y}$ protein is significantly lower, only $0.9 \mu \mathrm{M}$ (at $2.97 \mathrm{~s}$ ), which is $1.1 \%$ of the total protein concentration. The EPR spectra used to obtain the kinetic data for the tyrosine containing mutants (Figure 4B) are presented in Supporting Information Figures S1 and S2. The nature of the radicals in the two mutants is also different as they have distinctly different EPR line-shapes. The V63H/F42Y EPR signal has been simulated as a Tyr radical line-shape (Figure 5A).

Figure $4 \mathrm{C}$ shows the time course of the radicals in the $\mathrm{V} 63 \mathrm{H} / \mathrm{F} 42 \mathrm{Y}$ and V63H/F98Y proteins expressed as percentage to the ferryl concentration. The ferryl concentration was calculated at each time point from the measured ferric heme concentration (Figure S3) by using the formula [ferryl $](t)=$ $[\text { ferric }]_{0}-[$ ferric $](t)$, where $[\text { ferric }]_{0}=80 \mu \mathrm{M}$.

3.3. Effect of Electron Flow Pathways on MyoglobinInduced Lipid Oxidation. The increase of the rate constant of ferryl reduction in the tyrosine-containing proteins may affect the ability of these proteins to induce lipid oxidation. To test this hypothesis, the proteins were reacted with liposomes. Figure $5 \mathrm{~A}-\mathrm{C}$ shows the extent of lipid oxidation, measured by the formation of conjugated dienes that have an absorbance at $234 \mathrm{~nm}$ as a function of time. Conjugated dienes are formed, following free radical mediated oxidation, from the rearrangement of carbon double bond systems, such as the 1,4 cis-cis pentadiene (found in unsaturated lipids like linoleate and arachidonate). ${ }^{22,23}$ This conjugation can be used as a marker for lipid oxidation. We used CP20 as the reductant because CP20, in contrast to ascorbate, did not cause any significant reduction of the ferric $\mathrm{Mb}$ to the ferrous oxidation state over time scales used for the lipid oxidation experiment. The time course for lipid oxidation by the $\mathrm{V} 63 \mathrm{H}$ protein is typical of $\mathrm{Mb}$ or $\mathrm{Hb}$. Following a lag period, a lipid oxidation cascade occurs, showing a net increase in lipids with conjugated dienes (measured as absorbance at $234 \mathrm{~nm}$ ). The ability of the three proteins in this study to oxidize lipids is not significantly different, with lag periods of around 90-100 $\mathrm{min}$ and a maximum rate of conjugated diene formation of around 20-30 $\mathrm{nM} \mathrm{s}^{-1}$ (Figure 5 and Table 2). The presence of the reductant 

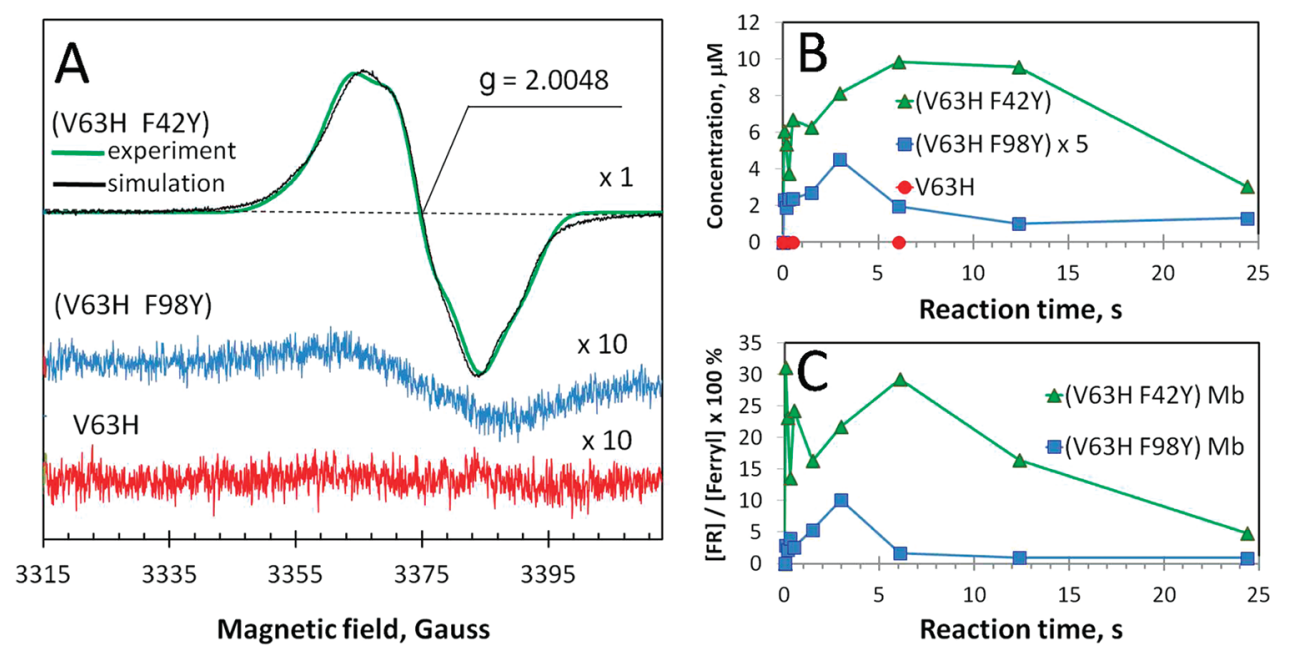

Figure 4. Formation of free radicals in Aplysia myoglobin. (A) The EPR spectra of the samples of three $80 \mu \mathrm{M}$ Aplysia Mb mutants freeze-quenched $6 \mathrm{~s}$ after mixing at $\mathrm{pH} 7.4$ with $80 \mu \mathrm{M} \mathrm{H}_{2} \mathrm{O}_{2}$ (both concentrations are after mixing). The EPR spectra do not contain the $g=2$ EPR signals from the high spin ferric heme as those have been subtracted as described in the Experimental Section. Also subtracted are the "baseline" signals of the EPR tubes or the resonator recorded for a blank sample (water). The V63H F42Y spectrum (green line) was simulated (black line) by using the parameters given in Table S1 that have been obtained by TRSSA for the input parameters of $\rho_{\mathrm{C} 1}=0.395$ and $\theta=50^{\circ}$ (see Discussion). The V63H/ F98Y (blue line) and $\mathrm{V} 63 \mathrm{H}$ (red line) signals are multiplied by a factor of 10. (B) Kinetic dependences of the free radicals in the course of reaction with $80 \mu \mathrm{M}$ peroxide for $80 \mu \mathrm{M} \mathrm{V63H} \mathrm{Mb} \mathrm{(red} \bullet$ ), V63H/F42Y Mb (green $\boldsymbol{\Delta}$ ), and (V63H/F98Y) Mb (blue $\mathbf{\square}$ ). The random error of concentration determination was found to be between $6 \%$ and $17 \%$. (C) The concentration of free radical for V63H/F42Y Mb (green $\boldsymbol{\Delta}$ ) and $\mathrm{V} 63 \mathrm{H} / \mathrm{F} 98 \mathrm{Y} \mathrm{Mb}$ (blue $\mathbf{a}$ ) expressed as a percentage to the ferryl Mb concentration. The EPR spectra were obtained at $10 \mathrm{~K}$ at the following instrumental conditions: microwave frequency $\nu_{\mathrm{MW}}=9.468 \mathrm{GHz}$, microwave power $P=0.05 \mathrm{~mW}$, modulation amplitude $A_{\mathrm{m}}=3 \mathrm{G}$, time constant $\tau$ $=82 \mathrm{~ms}$, scan rate $v=0.60 \mathrm{G} \mathrm{s}^{-1}$, number of scans per spectrum $\mathrm{NS}=1$.
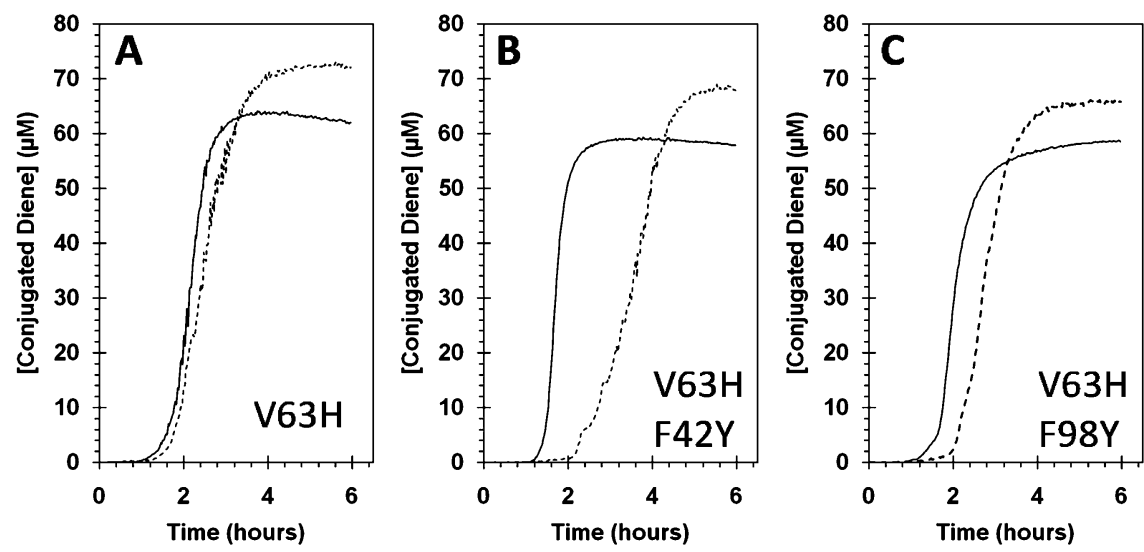

Figure 5. Oxidation of liposomes caused by the redox cycling of Aplysia $\mathrm{Mb}(1 \mu \mathrm{M})$ as measured by the formation of lipid-based conjugated dienes. The data for the tyrosine free $(\mathrm{A})$ and two tyrosine containing $\mathrm{Mb}$ mutants $(\mathrm{B}, \mathrm{C})$, in the absence (solid lines) and presence (dotted lines) of the reductant CP20 $(50 \mu \mathrm{M})$, are presented.

CP20 decreases the maximal rate of lipid peroxidation with all proteins, making the protein less effective at oxidizing lipids (Table 2). However, the decrease observed in the $\mathrm{V} 63 \mathrm{H} \mathrm{Mb}$ (7.7\% decrease) is not significant $(p=0.32)$. The maximal rate of lipid oxidation with the $\mathrm{V} 63 \mathrm{H} / \mathrm{F} 42 \mathrm{Y}$ protein is significant (54.0\% decrease, $p=0.048$ ) as it is with the V63H/F98Y protein $(33.1 \%$ decrease, $p=0.038)$. The change in the lag period, the time after addition of $\mathrm{Mb}$ before lipid oxidation cascades, is also affected in a similar fashion by the addition of CP20 (Table 2). In the case of the $\mathrm{V} 63 \mathrm{H} \mathrm{Mb}$, there was no significant change in lag period $(p=0.44)$, but there are significant changes in the cases of the variants with tyrosine in the lag period ( $p=0.065$ and 0.044 for $\mathrm{V} 63 \mathrm{H} / \mathrm{F} 42 \mathrm{Y}$ and V63H/F98Y, respectively), thus delaying the cascade of lipid oxidation in addition to the maximal rate of lipid oxidation.

\section{DISCUSSION}

The reduction of the ferryl heme iron involves electron transfer between the reducing agent and the iron either directly or via a through-protein electron-hopping pathway involving redox active tyrosine residues. We used the Aplysia $\mathrm{Mb}$ system to engineer these electron pathways. This approach has proved to be an excellent platform for examination of the mechanisms that govern such electron movements. The amino acids that are of interest lay close to the heme pocket but are also solvent exposed, similar to the redox active tyrosine residues in other globins such as horse $\mathrm{Mb}(\mathrm{Y} 103)$ and human $\mathrm{Hb} \alpha$ chain (Y42). ${ }^{9,10}$ However, our system exhibits overall rates of reduction of ferryl heme iron in Aplysia $\mathrm{Mb}$ by external reductants much higher than those that have been observed in 
Table 2. Effect of the Reductant CP20 on the Maximal Rate of the Conjugated Diene Formation and Lag Period

\begin{tabular}{cccc} 
& \multicolumn{3}{c}{ protein } \\
\cline { 2 - 4 } parameter & V63H & V63H/F42Y & V63H/F98Y \\
\cline { 2 - 4 } & Maximal Rate of Conjugated Diene Formation \\
$\begin{array}{c}\text { absence of reductant } \\
\left.(\mathrm{nM} \mathrm{s})^{-1}\right)\end{array}$ & $17.83 \pm 1.97$ & $27.26 \pm 6.52$ & $20.34 \pm 1.01$ \\
$\begin{array}{c}\text { presence of } 50 \mu \mathrm{M} \\
\left.\text { reductant }(\mathrm{nM} \mathrm{s})^{-1}\right)\end{array}$ & $16.46 \pm 2.83$ & $12.55 \pm 2.45$ & $13.61 \pm 2.61$ \\
$\begin{array}{c}\text { percentage change } \\
\text { absence of reductant } \\
(\text { min) }\end{array}$ & -7.7 & -54.0 & -33.1 \\
$\begin{array}{c}\text { presence of } 50 \mu \mathrm{M} \\
\text { reductant (min) }\end{array}$ & $100.9 \pm 1.3$ & $86.1 \pm 1.2$ & $98.2 \pm 15.4$ \\
percentage change & $99.7 \pm 10.8$ & $139.5 \pm 3.8$ & $133.4 \pm 4.2$ \\
\hline
\end{tabular}

other globins. These differences in electron transfer rates cannot be explained by changes in distances.

Reduction of the ferryl state of the $\mathrm{V} 63 \mathrm{H}$ protein, in the absence of any tyrosines, proceeds only via direct reduction of the heme iron by the electron-donating agent, the latter having to gain at least partial access to the heme pocket. The two phenylalanine residues were selected to introduce a multistep electron hopping pathway between the heme iron and exogenous reductants (Figure 6). In the protein, both direct and through-protein pathways for electron transfer are evident, observed through the double rectangular hyperbola rate constant profile (Figure 2). Introduction of tyrosine also enhances the rate of ferryl autoreduction (Figure 2, Table 1).

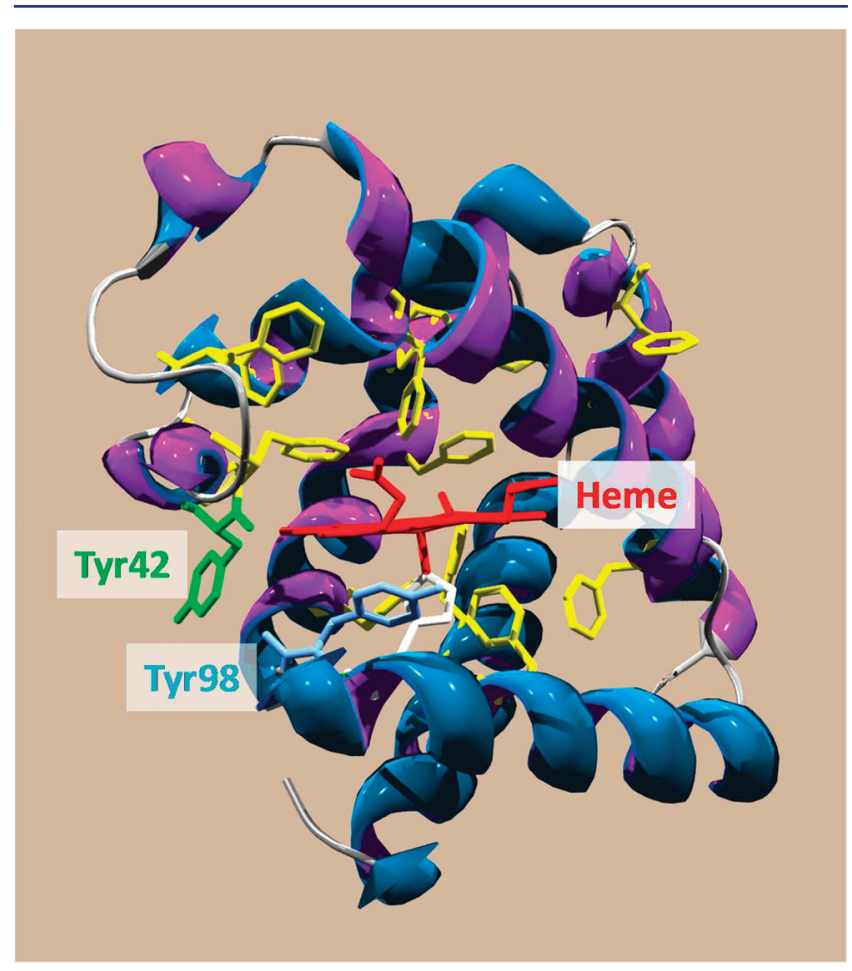

Figure 6. Aplysia myoglobin structure. Highlighted are the heme (red) and proximal histidine (white), 13 phenylalanine residues (yellow), and two phenylalanine residues Phe 42 and Phe98 replaced in the structure file by tyrosines (green and light blue, respectively). Structure file $1 \mathrm{MBA}^{33}$ from the Protein Data Bank (www.pdb.org/pdb) was used to generate the figure.
This ferryl to ferric heme autoreduction has previously been shown to be dependent on the presence of tyrosine residues, with the autoreduction rate of sperm whale ferryl $\mathrm{Mb}$ being decreased in the mutant in which all three Tyr residues were replaced with phenylalanines. ${ }^{26}$ In this work, we show that replacement of phenylalanines in the native protein with tyrosines has the opposite effect: the rate of the autoreduction of the ferryl heme is significantly increased. Such a decreased stability of the ferryl species in Aplysia proteins containing a tyrosine is consistent with the idea that tyrosines function as redox cofactors, facilitating electron flow to the ferryl heme iron. Mutagenesis to remove the redox active tyrosine residues between the radical initiation site and the distant active site of E. coli and mouse ribonucleotide reductase R1 and R2 subunits was effective, inhibiting the activity by between $98.4 \%$ and $99.7 \%$ with single point mutations. ${ }^{4,27-30}$ Similarly, the absence of the tyrosine in our short-range electron transfer pathway in Aplysia Mb decreases the electron transfer rate up to $99.93 \%$.

We have previously shown that the maximum rate constant of direct electron transfer between the reductant and heme iron is dependent on the chemical and physical properties of the reductant that defines its ability to gain access to the heme pocket. Therefore, small differences in the slope of the graphs (Figure 2) at higher $(>100 \mu \mathrm{M})$ reductant concentrations between the three proteins may represent minor changes in the accessibility of the reductant to the heme pocket arising from the presence or absence of the tyrosine residue close to the heme pocket. The $k_{\max }$ of ferryl reduction for the high affinity tyrosine-dependent electron transfer pathway has previously been shown to be essentially independent of the physical properties of the reductant used. ${ }^{9,24}$ This is consistent with the data presented in Figure 2 that show the $k_{\max }$ for the high affinity pathway for the reduction of ferryl V63H/F42Y or $\mathrm{V} 63 \mathrm{H} / \mathrm{F} 98 \mathrm{Y} \mathrm{Mb}$ by ascorbate is identical to the $k_{\max }$ found for the reduction of the same protein by CP20 (Table 1). Therefore, the maximum rate constant of electron transfer appears to be determined by the rate-limiting step of electron transfer between the tyrosine and heme iron. Previous results have shown that this electron transfer rate is in the range of $0.005-0.01 \mathrm{~s}^{-1}$ for horse $\mathrm{Mb}$ (Y103) human $\alpha$-chain $\mathrm{Hb}$ (Y42). 9,10,24 The addition of a tyrosine to Aplysia Mb results in a rate of electron transfer, which is several hundreds of times higher than in those globins. Addition of ascorbate enhances the ferryl reduction up to 780 -fold for the $\mathrm{V} 63 \mathrm{H} / \mathrm{F} 42 \mathrm{Y}$ protein as compared to the tyrosine free protein (at $2 \mu \mathrm{M}$ ascorbate) and 1310-fold for the V63H/F98Y protein (at $20 \mu \mathrm{M}$ ascorbate). These maximal enhancement values are even greater with CP20 as the reductant.

We have previously remarked that the electron transfer rate between the heme and a tyrosine $\sim 5 \AA$ away (as in most globins) should, according to the Marcus theory, be considerably faster than observed in our ferryl heme reduction experiments. ${ }^{9,24}$ Indeed, electron flow through metalloproteins have been demonstrated up to $20 \AA$ distance, with electron tunneling times in the millisecond time scale for metalloproteins such as $\mathrm{Mb}$ and cytochrome c, and projected picosecond time scales for distances of $\sim 5 \AA^{1}$. Our relatively low electron transfer rates can be explained by proposing that only a small percentage of the protein exists in a form that can participate in rapid transfer. This is in equilibrium with a much more highly populated inactive state. We propose that it is only within a subpopulation, such as $\left[\mathrm{Fe}^{4+}-\mathrm{OH}^{-}\right]---\mathrm{Tyr}-\mathrm{O}^{-}$, with a protonated oxoferryl and a deprotonated tyrosine, that electron 


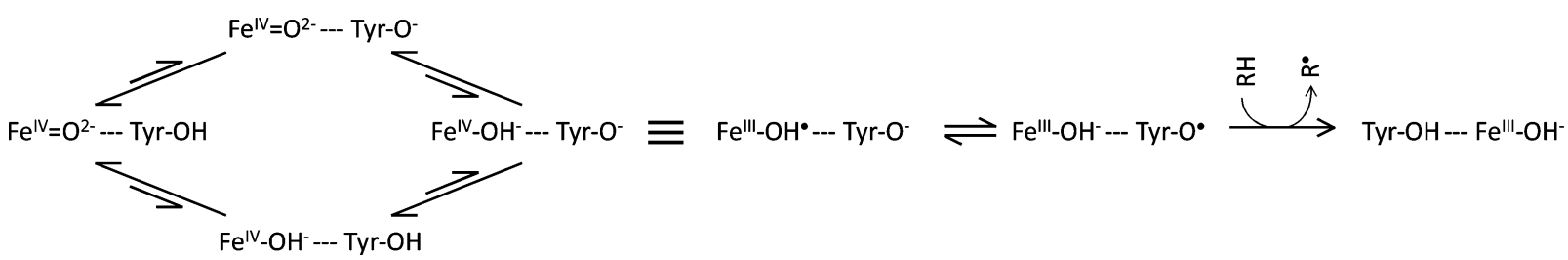

Figure 7. Proposed mechanism of electron movement from an external reductant to heme iron. At neutral $\mathrm{pH}$, the tyrosine and oxoferryl species are protonated and deprotaned, respectively. A small subpopulation of $\left[\mathrm{Fe}^{4+}-\mathrm{OH}^{-}\right]--\mathrm{Tyr}-\mathrm{O}^{-}$can be formed by deprotonation of the tyrosine $(\mathrm{pK} \approx$ $11)$ and a protonation of the oxoferryl state $(\mathrm{pK} \approx 4.5)$. The protonated ferryl species is equivalent to ferric plus a radical $\left(\left[\mathrm{Fe}^{\mathrm{III}}-\mathrm{OH}^{\bullet}\right]\right)$, the $\mathrm{radical}^{\circ}$ passing to the surface tyrosine and abstracting an electron from the reductant $\left(\mathrm{RH} \rightarrow \mathrm{R}^{\bullet}\right)$. Thus, rapid electron movement from the reductant to the heme iron occurs in a small population of the protein.

transfer occurs via a Marcus mechanism (Figure 7). This mechanism is similar to the proton-coupled tyrosyl radical transfer mechanism discussed in detail for ribonuclotide reductase. ${ }^{3,4,31}$ Because the $\mathrm{p} K_{\mathrm{a}}$ values for protonated/ deprotonated states of these species are far apart $(\sim p H 4.5$ for the ferryl ${ }^{8}$ and $\sim \mathrm{pH} 11$ for the tyrosine $\mathrm{e}^{32}$ ), the fraction of the protein that accounts for electron transfer is minute. The proposal that the "active" subpopulation of the proteins is in the $\left[\mathrm{Fe}^{4+}-\mathrm{OH}^{-}\right]---\mathrm{Tyr}-\mathrm{O}^{-}$state allows an explanation of the observation that the maximal rate of ferryl reduction is largely independent of $\mathrm{pH}$, with the population of the "active" species staying relatively constant. Thus, an increase in electron transfer rate between the reductant and the heme iron of 2 orders of magnitude, as seen in Aplysia, may reflect either a small shift in the $\mathrm{p} K_{\mathrm{a}}$ for the protonation of the oxoferryl heme iron or the deprotonation of the tyrosine. Whether the addition of a tyrosine close to the heme changes the $\mathrm{p} K_{\mathrm{a}}$ for the protonation of the oxyferryl heme is currently unknown. In silico virtual mutation of the phenylalanines in positions 42 and 98 to tyrosines shows that the closest distance between the phenyl ring of the tyrosine and the heme ring is $5.7 \AA$ for the $\mathrm{V} 63 \mathrm{H} /$ F42Y protein and $4.3 \AA$ for the V63H/F98Y protein (Figure 6). Thus, the difference between the kinetic parameters of ferryl heme reduction in the $\mathrm{V} 63 \mathrm{H} / \mathrm{F} 42 \mathrm{Y}$ and $\mathrm{V} 63 \mathrm{H} / \mathrm{F} 98 \mathrm{Y}$ proteins could potentially be explained by the different proximity of the tyrosines in these proteins to the heme. In silico mutations also suggest that the hydroxyl group of the tyrosine residue for the Y42 is open to the bulk solution, whereas the hydroxyl group of Y98 is close to the protein/surface interface and may interact with other residues through hydrogen bonding. A glutamate (E94) residue is close $(<4 \AA)$ enough to the oxygen of Y98 to form a hydrogen bond with only a small movement of the E94 residue (Figure S4). Thus, a hydrogen atom may be shared between these two residues and allow easier deprotonation of Y98, essentially shifting the $\mathrm{p} K_{\mathrm{a}}$ to a lower value and therefore enhancing the electron transfer. The hydroxyl group of Y42, however, can only make hydrogen bonds with water, so that deprotonation of this residue is more difficult.

The maximum yield of the radicals is very different in the mutants studied. It is highest in the V63H/F42Y variant, lower in V63H/F98Y, and below detection level in the tyrosine free mutant V63H (Figure 4). It is possible that the lower yield, and hence stability, of the Y98 radical in V63H/F98Y is related to a $3.4 \AA$ hydrogen bonding predicted between E94 and Y98 (Figure S4); however, with only two examples this theory requires further testing. It should also be noted that we previously reported formation of a free radical in the wild type (WT) recombinant protein, also without tyrosines, when the slow-freeze method of making EPR samples was employed. ${ }^{17}$ The maximal observable yield of that radical, tentatively assigned to the only histidine in the protein, the proximal histidine H95, was slightly lower than that of the V63H/F98Y radical in the present study $(0.25$ vs $0.8 \mu \mathrm{M})$.

It is often difficult to assign radicals that have unresolved or poorly resolved EPR spectra. However, in this case, simulation of the V63H/F42Y EPR spectrum clearly shows this to originate from a tyrosyl radical (Figure 4A). Because there is only one tyrosine residue in the $\mathrm{Mb}$ variant, the radical must be located on this, Y42. Furthermore, the simulation determines the ring rotation angle $\theta$ in the radical to be equal to $50.0^{\circ}$ (Table S1) similar to the angle $\left(56.3^{\circ}\right)$ for residue $\mathrm{F} 42$ in the wild type, as determined from the crystal structure file $1 \mathrm{MBA} .{ }^{33}$ This information both validates the TRSSA algorithm that identifies the tyrosine residue on which a radical is located and also supports our assumption that substituting phenylalanine for tyrosine at this location has a minor effect on structure. The EPR illustrates that these tyrosines can accommodate radicals, the same tyrosines that are required to form a radical species for radical migration to occur between the heme iron and the reductant resulting in election flow in the opposite direction (Figure 7). However, it should be noted that the primary radical generated concurrent with the ferryl (Figures 3 and 4) may have properties different from those of the radical intermediate predicted to result from ferryl reduction (Figure 7). This is due to the proximity of the radical to ferryl and ferric heme iron for the primary and proposed radical intermediate for ferryl reduction, respectively.

The ability of $\mathrm{Mb}$ to oxidize liposomes is relatively unchanged in the three mutants studied (Figure 5 and Table 2 ). This implies that the presence or absence of the tyrosinebased pathway does not affect the intrinsic ability of $\mathrm{Mb}$ to induce lipid oxidation. Therefore, this pathway cannot on its own promote lipid oxidation reactions. Introduction of a reductant partial protects the liposomes from peroxidation, decreasing the maximal rate of lipid oxidation and increasing the lag period before lipid oxidation cascades. These effects are most likely due to the reduction of ferryl $\mathrm{Mb}$ before the ferryl species is able to react with lipids. There may also be some effect from the reductants scavenging the protein radical generated in association with ferryl heme iron. Higher levels of conjugated diene formation in the presence of reductants do not denote higher levels of oxidation but merely a change in the mechanism of lipid radical attack. The degree of protection afforded by the reductant is significantly different in the three proteins. Mutation of the protein to introduce the tyrosinebased electron transfer pathway results in significantly greater protection to the $\mathrm{Mb}$-induced lipid oxidation as compared to the $\mathrm{V} 63 \mathrm{H}$ protein (Figure 5 and Table 2), with the V63H/ F42Y protein showing the greatest level of protection, 
increasing the lag period and decreasing the maximal rate of lipid oxidation by at least $50 \%$.

Cell-free $\mathrm{Mb}$ and $\mathrm{Hb}$ are known to participate in damaging oxidative redox chemistry under pathological conditions. ${ }^{34-36}$ The use of modified $\mathrm{Hb}$ for HBOCs as potential semisynthetic blood substitutes has failed during clinical studies. One proposal is that oxidative damage inflicted by cell-free $\mathrm{Hb}$ is a major cause of toxicity. This problem may be ameliorated if the oxidative capacity of $\mathrm{Hb}$ could be manipulated. This study provides proof of principle that efficient tyrosine-based electron transfer pathways may be used in the design of modified HBOCs that cause much less oxidative damage when used in conjunction with low concentrations of reductants.

This study confirms, in a model system, that the addition of tyrosines to specific sites on the $\mathrm{Mb}$ molecule can greatly enhance the reduction of ferryl $\mathrm{Mb}$ by exogenously added reductants, facilitating electron transfer between the reductant and the ferryl heme iron and preventing lipid oxidation. While in human $\mathrm{Hb}$ the elimination of the tyrosine pathway in the $\alpha$ chain (Y42F) or the addition of this pathway to the $\beta$ chain (F41Y) shows the rate of electron transfer to be altered by an order of magnitude, in the case of Aplysia $\mathrm{Mb}$ much larger changes were observed.

\section{ASSOCIATED CONTENT}

\section{S Supporting Information}

EPR spectra and time courses for Aplysia myoglobin V63H/ F42Y and V63H/F98Y mutants, in silico mutation of F42 and F98 to tyrosine, hypothesized hydrogen bonding of Y42 to water and Y98 to E94, and TRSSA generated parameters used to simulate the $(\mathrm{V} 63 \mathrm{H} / \mathrm{F} 42 \mathrm{Y})$ spectrum. This material is available free of charge via the Internet at http://pubs.acs.org.

\section{AUTHOR INFORMATION}

\section{Corresponding Author}

reedb@essex.ac.uk

\section{Notes}

The authors declare no competing financial interest.

\section{ACKNOWLEDGMENTS}

We acknowledge the BBSRC for funding (grants BBF0076631 and BBE02355X1) and Prof Francesca Cutruzzolà (University of Rome, La Sapienza) for donation of the Aplysia faciata myoglobin gene and helpful advice in its handling. We would like to thank an anonymous reviewer of this Article for pointing out that a molecular mechanics calculation with AMBER 99 force field supports the idea of a hydrogen-bond formation between Tyr98 and Glu94, giving additional weight to our hypothesis that protonation of the tyrosine is important for electron transfer.

\section{REFERENCES}

(1) Gray, H. B.; Winkler, J. R. Biochim. Biophys. Acta 2010, 1797, 1563-1572.

(2) Shih, C.; Museth, A. K.; Abrahamsson, M.; Blanco-Rodriguez, A. M.; Di Bilio, A. J.; Sudhamsu, J.; Crane, B. R.; Ronayne, K. L.; Towrie, M.; Vlcek, A., Jr.; Richards, J. H.; Winkler, J. R.; Gray, H. B. Science 2008, 320, 1760-1762.

(3) Reece, S. Y.; Hodgkiss, J. M.; Stubbe, J.; Nocera, D. G. Philos. Trans. R. Soc. London, Ser. B 2006, 361, 1351-1364.

(4) Stubbe, J.; Nocera, D. G.; Yee, C. S.; Chang, M. C. Chem. Rev. 2003, 103, 2167-2201.
(5) Seyedsayamdost, M. R.; Reece, S. Y.; Nocera, D. G.; Stubbe, J. J Am. Chem. Soc. 2006, 128, 1569-1579.

(6) Aubert, C.; Vos, M. H.; Mathis, P.; Eker, A. P.; Brettel, K. Nature 2000, 405, 586-590.

(7) Reeder, B. J.; Wilson, M. T. Free Radical Biol. Med. 2001, 30, 1311-1318.

(8) Silaghi-Dumitrescu, R.; Reeder, B. J.; Nicholls, P.; Cooper, C. E.; Wilson, M. T. Biochem. J. 2007, 403, 391-395.

(9) Reeder, B. J.; Cutruzzola, F.; Bigotti, M. G.; Hider, R. C.; Wilson, M. T. Free Radical Biol. Med. 2008, 44, 274-283.

(10) Reeder, B. J.; Grey, M.; Silaghi-Dumitrescu, R. L.; Svistunenko, D. A.; Bulow, L.; Cooper, C. E.; Wilson, M. T. J. Biol. Chem. 2008, 283, 30780-30787.

(11) Natanson, C.; Kern, S. J.; Lurie, P.; Banks, S. M.; Wolfe, S. M. JAMA, J. Am. Med. Assoc. 2008, 299, 2304-2312.

(12) Alayash, A. I. Artif. Cells, Blood Substitutes, Immobilization Biotechnol. 2001, 29, 415-425.

(13) Alayash, A. I.; Patel, R. P.; Cashon, R. E. Antioxid. Redox Signaling 2001, 3, 313-327.

(14) McLeod, L. L.; Alayash, A. I. Am. J. Physiol. 1999, 277, H92-99.

(15) Rogers, M. S.; Patel, R. P.; Reeder, B. J.; Sarti, P.; Wilson, M. T.; Alayash, A. I. Biochem. J. 1995, 310, 827-833.

(16) Thompson, M. K.; Franzen, S.; Ghiladi, R. A.; Reeder, B. J.; Svistunenko, D. A. J. Am. Chem. Soc. 2010, 132, 17501-17510.

(17) Svistunenko, D. A.; Reeder, B. J.; Wankasi, M. M.; SilaghiDumitrescu, R. L.; Cooper, C. E.; Rinaldo, S.; Cutruzzola, F.; Wilson, M. T. Dalton Trans. 2007, 840-850.

(18) Svistunenko, D. A.; Davies, N.; Brealey, D.; Singer, M.; Cooper, C. E. Biochim. Biophys. Acta 2006, 1757, 262-272.

(19) Nilges, M. J.; Matteson, K.; Bedford, R. L. ESR Spectroscopy in Membrane Biophysics. In Biological Magnetic Resonance; Hemminga, M. A., Berliner, L. Eds.; Springer: New York, 2007; Appendix 2.

(20) Svistunenko, D. A.; Cooper, C. E. Biophys. J. 2004, 87, 582-595.

(21) Reeder, B. J.; Wilson, M. T. Chem. Res. Toxicol. 2005, 18, 10041011.

(22) Egmond, M. R.; Brunori, M.; Fasella, P. M. Eur. J. Biochem. 1976, 61, 93-100.

(23) Reeder, B. J.; Wilson, M. T. Biochem. J. 1998, 330, 1317-1323.

(24) Reeder, B. J.; Hider, R. C.; Wilson, M. T. Free Radical Biol. Med. 2008, 44, 264-273.

(25) Peisach, J.; Blumberg, W. E.; Ogawa, S.; Rachmilewitz, E. A.; Oltzik, R. J. Biol. Chem. 1971, 246, 3342-3355.

(26) Lardinois, O. M.; Ortiz de Montellano, P. R. Biochemistry 2004, 43, 4601-4610.

(27) Ekberg, M.; Potsch, S.; Sandin, E.; Thunnissen, M.; Nordlund, P.; Sahlin, M.; Sjoberg, B. M. J. Biol. Chem. 1998, 273, 21003-21008.

(28) Ekberg, M.; Sahlin, M.; Eriksson, M.; Sjoberg, B. M. J. Biol. Chem. 1996, 271, 20655-20659.

(29) Rova, U.; Adrait, A.; Potsch, S.; Graslund, A.; Thelander, L. J. Biol. Chem. 1999, 274, 23746-23751.

(30) Rova, U.; Goodtzova, K.; Ingemarson, R.; Behravan, G.; Graslund, A.; Thelander, L. Biochemistry 1995, 34, 4267-4275.

(31) Yee, C. S.; Chang, M. C.; Ge, J.; Nocera, D. G.; Stubbe, J. J. Am. Chem. Soc. 2003, 125, 10506-10507.

(32) Wilbur, D. J.; Allerhand, A. J. Biol. Chem. 1976, 251, 51875194.

(33) Bolognesi, M.; Onesti, S.; Gatti, G.; Coda, A.; Ascenzi, P.; Brunori, M. J. Mol. Biol. 1989, 205, 529-544.

(34) Holt, S.; Reeder, B.; Wilson, M.; Harvey, S.; Morrow, J. D.; Roberts, L. J., II; Moore, K. Lancet 1999, 353, 1241.

(35) Moore, K. P.; Holt, S. G.; Patel, R. P.; Svistunenko, D. A.; Zackert, W.; Goodier, D.; Reeder, B. J.; Clozel, M.; Anand, R.; Cooper, C. E.; Morrow, J. D.; Wilson, M. T.; Darley-Usmar, V.; Roberts, L. J., II. J. Biol. Chem. 1998, 273, 31731-31737.

(36) Reeder, B. J.; Sharpe, M. A.; Kay, A. D.; Kerr, M.; Moore, K.; Wilson, M. T. Biochem. Soc. Trans. 2002, 30, 745-748. 